\title{
SEXUAL AND GEOGRAPHIC VARIATION OF COLOR PATTERNS IN LIOLAEMUS TENUIS (SQUAMATA, LIOLAEMINAE)
}

\author{
VARIACION SEXUAL Y GEOGRAFICA DE PATRONES DE COLORACION EN \\ LIOLAEMUSTENUIS (SQUAMATA, LIOLAEMINAE)
}

\author{
Marcela A. Vidal ${ }^{1, *}$, Juan Carlos Ortiz ${ }^{1} \&$ Antonieta Labra ${ }^{2}$ \\ ${ }^{1}$ Departamento de Zoología, Facultad de Ciencias Naturales y Oceanográficas, Universidad de Concepción, \\ Casilla 160-C, Fax (41) 2389 82, Concepción, Chile. \\ ${ }^{2}$ Centre for Ecological and Evolutionary Synthesis (CEES), Department of Biology, University of Oslo, P.O. Box \\ 1066 Blindern, N-0316 Oslo, Norway. \\ "Corresponding author: M.A. Vidal. E-mail: marvidal@udec.cl
}

\begin{abstract}
We studied sexual and geographic variation of color patterns in the lizard Liolaemus tenuis. We counted the number of scales with different colors in two body regions, in individuals of both sexes, from three groups of populations along a latitudinal range. Color patterns showed sexual and geographic variations; females and the northern group were the darkest. The selective pressures of these color pattern variations are unclear. However, considering that $L$. tenuis males are territorial and polygamous, we postulate that sexual variation in color would be consequence of sexual selection involving female choice and male-male interactions (e.g. agonistic displays among males). Geographic variation may be determined by predation pressure, as there is a tendency to a color matching with the predominant color of the environment (i.e. predominance of dark colors towards scrublands).
\end{abstract}

Keywords: Chromatophores, sexual dimorphism, lizard, Liolaemus, Chile.

\section{RESUMEN}

Se estudió la variación sexual y geográfica de los patrones de coloración en Liolaemus tenuis. Se contó el número de escamas con diferentes colores en dos regiones del cuerpo, en individuos de ambos sexos y provenientes de tres grupos de poblaciones a lo largo de un gradiente latitudinal. Los patrones de coloración mostraron variaciones sexuales y geográficas; las hembras y el grupo más nortino fueron más oscuros. Las presiones selectivas que determinan estas variaciones de los patrones de coloración no son claras. Sin embargo, considerando que los machos de L. tenuis son territoriales y polígamos, se postula que la variación sexual del color sería una consecuencia de la selección sexual que involucra elección de machos por parte de las hembras y las interacciones macho-macho (e.g. despliegues agonísticos entre machos). La variación geográfica estaría determinada por presiones de depredación, dada la tendencia a la presencia de coloraciones similares a las predominantes en el ambiente (i.e. predominio de colores oscuros hacia las zonas de matorral).

Palabras claves: Cromatóforos, dimorfismo sexual, lagartijas, Liolaemus, Chile. 


\section{INTRODUCTION}

Animal color patterns have received significant attention from different fields, including ecology, physiology and systematic (e.g. Cole 1943; Donoso-Barros 1966; Cei 1986). One of the main generalizations reached is that color patterns constitute adaptive evolutionary characters, representing a compromise between two main selective forces, sexual and natural selection (e.g. Endler 1978, 1986; Andersson 1994). In reptiles, sexual selection through female mate choice and/ or male-male competition, usually determines the occurrence of colorful males particularly during the reproductive season (Cooper et al. 1983; Cooper 1988; Watkins 1997); females can choose males based, among others, on visual displays in which color patterns are highly relevant (Jenssen 1977; Hews et al. 1997). Natural selection acts through predation and thermoregulation (e.g. Endler 1978). Thus, diurnal reptiles exposed to visual predators experience an intense selection for substrate matching to diminish their vulnerability to these predators (Brown \& Thorpe 1991; Stuart-Fox et al. 2004). On the other hand, dark colors, which absorb more heat, occur with higher frequency in animals from environments with lower temperature (Norris 1967; Pearson 1977; Belliure et al. 1996).

Intraspecific color variation has been described in many Liolaemus lizards (Donoso-Barros 1966; Ortiz 1981; Cei 1986, 1993; Pincheira \& Nuñez 2005). However, there is no quantification of these variations (but see Quatrini et al. 2001), which is the fundamental step to understand the factors that determine this variation. For example, it has been indicated that $L$. tenuis has sexual and geographic color variation (Müller \& Hellmich 1933; DonosoBarros 1966; Vidal et al. 2004). Males, in contrast to the melanistic (dark) coloration of females, are described as very colorful with predominance of yellow in the anterior part of the body, and bluegreen in the posterior part (Donoso-Barros 1966). Additionally, southern populations associated to dense forests, have been described as more colorful, with intense blue and yellow, than northern populations (more brownish), inhabiting open scrublands (Müller \& Hellmich 1933; Donoso-Barros 1966). As a first step in the understanding of the selective pressure involved in the color pattern variations of $L$. tenuis, we quantified the geographic and sexual color variation in color patterns along a latitudinal range in Chile.

\section{MATERIALS AND METHODS}

Liolaemus tenuis is an arboreal species with a wide geographic distribution in Chile, from sea level up to $1800 \mathrm{~m}$, and from 29 to $39^{\circ} \mathrm{S}$ (Donoso-Barros 1966; Veloso \& Navarro 1988). During springsummer of 2001-2002, lizards were collected at 10 different localities in Chile (Fig. 1). The exact geographic coordinates of the collecting localities can be found in Appendix I. Based on geographic proximity and similarities of the thermal conditions of the different localities (Di Castri 1968), we grouped them in three major groups: northern, central, and southern. Sample sizes by sexes and groups are show in Figure 2. Lizards were transported to the laboratory, measured (snout-vent length, SVL, $\mathrm{mm}$ ) and at the end of experiments (see below) they were sacrificed, fixed in alcohol (70\%), and deposited in the Museo de Zoología of Universidad de Concepción (see Appendix I). Color patterns were determined after expose individuals to a solar radiation of a typical sunny day $(16747 \pm 1139$ LUX) for one hour. This allowed the maximal expansion of chromatophores, thus the highest color expression. Thereafter, lizards were photographed with a metric (mm) and chromometric scales for standardization Pictures were taken with a digital camera (Sony Mavica), in two dorsal regions: a) anterior, between the forelimbs and b) posterior, between the hindlimbs. Pictures were scanned and we counted directly on the computer screen, the number of scales with pigments of different colors in one $\mathrm{cm}^{2}$ of the skin, whose center was fixed at the crossing of body midline and the line of girdles. Liolaemus tenuis is a small species ( $\mathrm{SVL}=50.08 \pm 4.32 \mathrm{~mm}$ (mean \pm standard error, see Vidal 2002)); thus, the frame of one $\mathrm{cm}^{2}$, basically covered the whole space between members, in each girdle. Following Skoknic (1957), scales were classified according the chromatophore present as blue (cyanophore), green (chlorophore), yellow (xanthophore), red (rodophore), black (melanophore), white (leucophore) and brown (guanophore).

Factors considered in the analyses were sex, group of localities, and the interaction between these two factors. Assumptions of statistical tests were 
evaluated using the Kolmogorov-Smirnov test for normality, and the Levene test for homogeneity of variance. No transformation was necessary in any case. Each color as a variable and body regions (anterior and posterior) were analyzed by a two-way and one-way MANCOVA respectively, with SVL as covariate. Thereafter, each color was analyzed separately, determining the effect of the different factors (sex and group) with a two-way ANCOVA with SVL as covariate, followed by Tukey for multiple comparisons. All analyses were performed in Systat 10.0 (SPSS 2000).

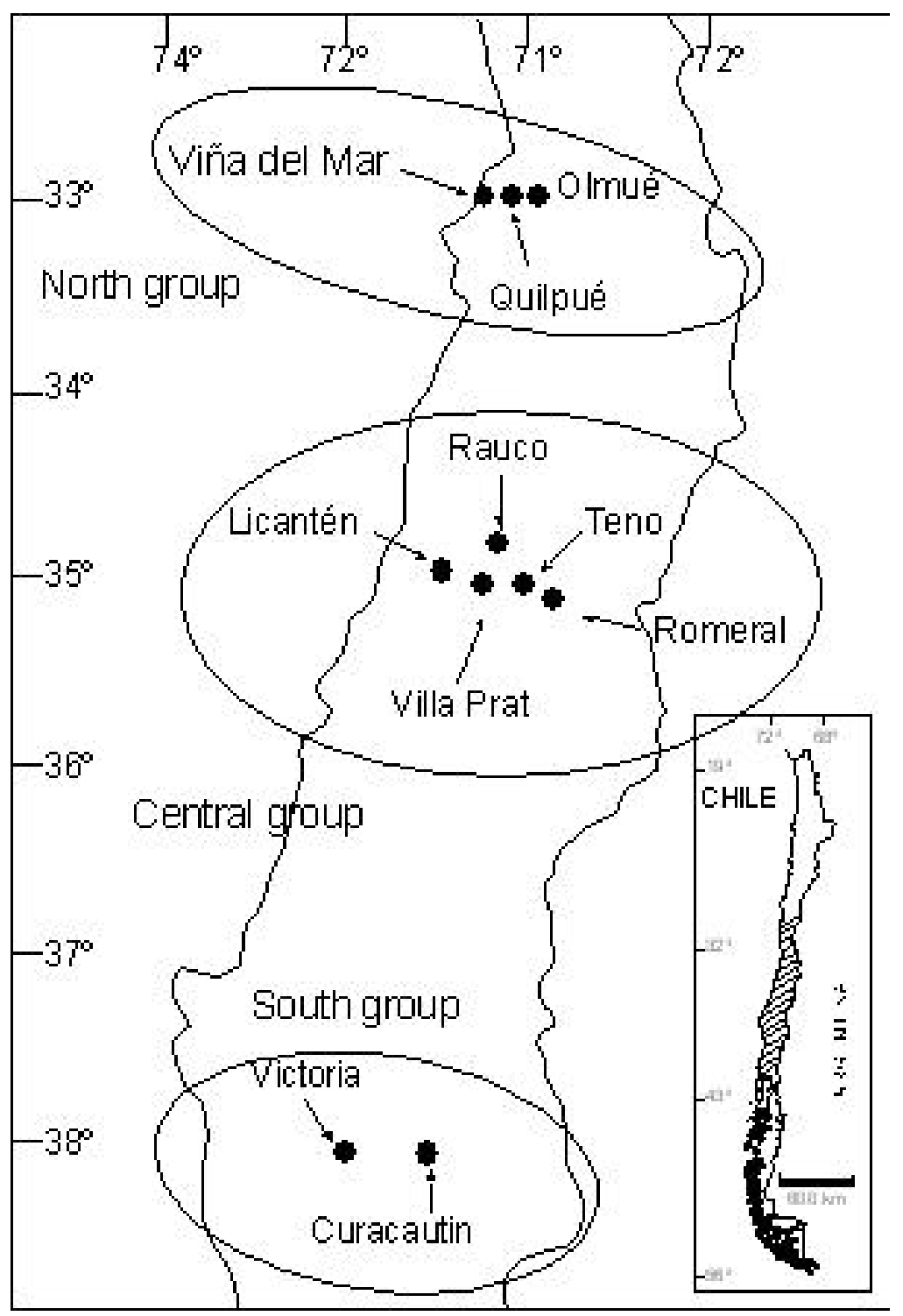

FIGURE 1. Geographic location of the collecting sites of different populations of Liolaemus tenuis, and the aggregation of these localities in three groups: north, central and south. Insert: Approximated distribution of L. tenuis in Chile.

FIGURA 1. Localización geográfica de los sitios de recolecta de diferentes poblaciones de Liolaemus tenuis y la agregación de estas localidades en tres grupos: norte, centro y sur. Inserto: Distribución aproximda de L. tenuis en Chile. 


\section{RESULTS}

The dorsal region of L. tenuis has five types of chromotophores: blue, black, yellow, green and brown. In Figure 2 is shows the number of scales with different colors in one $\mathrm{cm}^{2}$ of skin, in the three groups, separated by sexes and body regions. In general, independent of the sex and group, yellow pigments were only present in the anterior region, while blue was mainly present in the posterior body region (Fig. 2). The body regions differed in color presence (Wilks' Lambda $=0.095, P<0.001$; see Fig. 2 ) of the blue, green, yellow and black $(P<0.0001)$. Additionally, the geographic variation in the presence of the different colors, in both sexes, was only reflected in the abundance of brown and green scales; from north to south, brown scales decreased and green scales increased (Fig. 2).

The presence of all colors (except yellow) in both body regions was associated to the sex (Wilks' Lambda = $0.027, P<0.001$ ), to the group (Wilks' Lambda $=0.338$, $P<0.001$ ) and to their interaction (Wilks' Lambda = $0.342, P<0.001$ ), as is shown in Figure 2. Females were melanistic, and males colorful. In the anterior body region, sexual differences were in the number of green, brown, and black scales. Males had more green scales $(P<0.002)$, while females had more black $(P<0.003)$ and brown scales $(P<0.0006)$. In the posterior body region, males had more blue scales $(P<0.0001)$, while females had more green $(P<0.001)$ and brown scales $(P<0.0001)$. Population groups differed significantly in the presence of green, black, and brown scales $(P<$ $0.0001)$. The northern group had in the anterior body region, significantly more brown scales than the other two groups $(P<0.001)$, and the central group had more black scales than the other groups $(P<0.001$, Fig. 2$)$. In the posterior body region, southern group had significantly more green scales than the two other groups $(P<0.001)$, while the central group had more black scales than the other groups $(P<0.001)$. Additionally, brown scales were more abundant in the northern group $(P<0.001$, Fig. 2$)$.

\section{DISCUSSION}

Liolaemus tenuis showed sexual and geographic variation in color patterns, as was previously proposed (Müller \& Hellmich 1933; Donoso-Barros 1966; Vidal et al. 2004), but not quantified. Sexual differences were evident in both body regions (anterior: between forelimbs and posterior: between hindlimbs). Females were melanistic, with predominance of dark scales (brown and black) in both body regions, while colorful males had more green and blue scales in the anterior and posterior regions, respectively. We postulate that sexual selection may be an important factor maintaining this sexual color difference. Males can use color pattern as a warning mechanism to other males, as well as to attract females (Andersson 1994). In fact, L. tenuis has a polyginic social system; males are highly territorial (Manzur \& Fuentes 1979) and use visual displays in interactions with other males (Trigosso-Venario et al. 2002). Base on this, it is likely that color patterns are relevant mechanism for intraspecific communication.

Geographic variations in the total number of green and brown scales follow a latitudinal cline; from north to south (i.e. from scrubland to forest), there was a general increment in the number of green scales and a decrement in the quantity of brown scales. Additionally, in both body regions males showed an increase in the number of blue scales from north to south, but not in yellow scales, as has been previously indicated by Müller \& Hellmich (1933) and Donoso-Barros (1966). The populations included in this study have significant levels of gene flow, and the geographical arrangement of the genetic (allozyme) variation (Vidal et al. 2004) is not concordant with the geographic variation recorded in the color patterns. Altogether, these results suggest that the clinal variation in the color pattern may be consequence of an adaptive response to some environment factor (Brown \& Thorpe 1991). Future studies will unravel the putative selective pressure underlining this geographic color variation. However, the tendency to match the predominant environmental color (i.e. green scales increase toward the south [forest] and brown scales towards the north [scrubland]), allows postulating that predation may be the selective pressure that determine this polymorphism. A substrate color matching reduces the possibility that visual predators detect lizards (e.g. Stuart-Fox et al. 2003), such as raptors, normal predators of lizards (Jaksic et al. 1982). On the other hand, thermoregulation is usually claimed as another important factor to explain color patterns variation, particularly in ectotherms; dark species or populations tend to be more abundant in environments with lower 
temperatures (Pearson 1977; Forsman 1995), since dark colorations favor faster heating (Norris 1967). In the case of L. tenuis, however, thermoregulation would not be the factor that explains its color pattern variation. First, the darkest group inhabits environments with higher temperature, and second, this group as well as the melanistic females showed the slowest heating rates (Vidal 2002). Therefore, we propose that colors in L. tenuis may not play a key role in thermoregulation, and future studies will help to unravel the thermoregulatory mechanisms used by L. tenuis to cope with the clinal thermal variation.

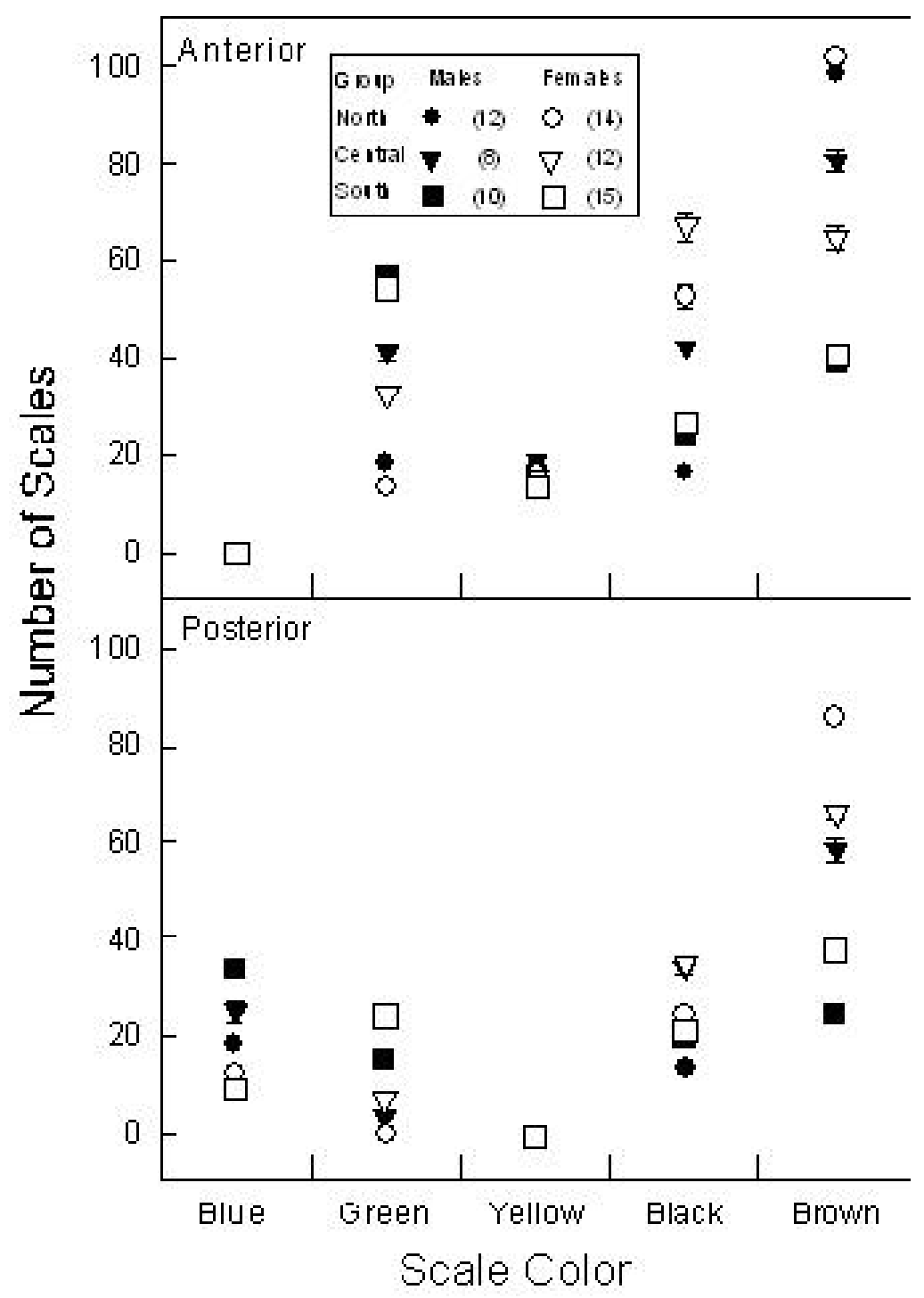

FIGURE 2. Mean number of scales $( \pm \mathrm{SE})$ with different pigmentation in one $\mathrm{cm}^{2}$ in two dorsal body-regions of Liolaemus tenuis. Data is present separated for each sex, and for the three groups (norther, central, and souther). In the box is indicated the sample sizes by group and sex. Body regions: A) anterior (between forelimbs) and B) posterior (between hindlimbs).

FIGURA 2. Número promedio de escamas $( \pm \mathrm{EE})$ con diferente pigmentación en un $\mathrm{cm} 2$ en dos regiones dorsales del cuerpo de Liolaemus tenuis. Los datos son presentados separados para cada sexo y para los tres grupos (norte, centro y sur). En la casilla esta indicado el tamaño de muestra por grupo y sexo. Las regiones de cuerpo son: A) anterior (entre las extremidades anteriores) y B) posterior (entre las extremidades posteriores). 


\section{ACKNOWLEDGMENTS}

This study was part of the Master Thesis in Science of MAV (Departamento de Zoología, Universidad de Concepción). Authors thanks to V. Jerez, R. Moreno, M. Fernández and R. Cifuentes by their invaluable assistance in the field; to M. Lamborot, G. D'Elía, and one anonymous reviewer for their significant contribution to the early version of manuscript. This study was partly funded by Fondecyt 1980115 to JCO and 3990021 to AL.

\section{BIBLIOGRAPHY}

Andersson, M. 1994. Sexual selection. Princeton University Press. New Jersey.

Belliure, J., L. M. Carrascal, \& J. Díaz. 1996. Covariation of thermal biology and foraging mode in two mediterranean lacertid lizards. Ecology 77:1163-1173.

Brown, R. P. \& R. S. Thorpe. 1991. Within island microgeographic variation in the colour pattern of the skink, Chalcides sexlineatus: pattern and cause. J. Evol. Biol. 4:557-574.

CEI, J. M. 1986. Reptiles del centro, centro-oeste y sur de la Argentina. Herpetofauna de las zonas áridas y semiáridas. Mus. Reg. Sci. Nat., Torino Monography 4.

CeI, J. M. 1993. Reptiles de noroeste, nordeste y este de la Argentina. Herpetofauna de las selvas subtropicales, Puna y Pampas. Mus. Reg. Sci. Nat., Torino Monography 11.

Cole, L. C. 1943. Experiments on toleration of high temperature in lizards with references to adaptative coloration. Ecology 24:94-108.

COoper, W. E. 1988. Sceloporus undulates consobrinus (southern prairie lizard). Coloration. Herpetol. Rev. 19:34.

Cooper, W. E., C. S. Adams \& J. L. Dobie. 1983. Female color change in the keeled earless lizard, Holbrookia propinqua: Relationship to the reproductive cycle. Southwestern Nat. 28:275280.

Di CAstri, F. 1968. Esquisse ecologique du Chili. In C. D. Deboutteville and T. Rapoport (eds.), Biologie de 1'Amérique Austral, pp. 7-52. Edition du Centre National de la Recherche Scientifique, Paris.

Donoso-Barros, R. 1966. Reptiles de Chile. Ediciones Universidad de Chile. Santiago de Chile.

Endler, J. A. 1978. A predator's view of animal color patterns. Evol. Biol. 11:319-364.

Endler, J. A. 1986. Defenses against predators. In M. Feder and G. Lauder (eds.), Predator-prey relationship: Perspectives and approaches from the study of lower vertebrates, pp. 109-134. University of Chicago Press, Chicago.
Forsman, A. 1995. Heating rates and body temperature variation in melanistic and zigzag Vipera berus: does colour make a difference? Ann. Zool. Fenn. 32:365-374.

Hews, D. K., C. W. Thompson, I. T. Moore \& M. C. Moore. 1997. Population frequencies of alternative male phenotypes in tree lizards: geographic variation and common-garden rearing studies. Behav. Ecol. Sociobiol. 41:371-380.

Jaksic, F.M., H.W. Greene, K.S. Schewenk \& R.L. Seib. 1982. Predation upon reptiles in Mediterranean habitats of Chile, Spain and California: A comparative analysis. Oecologia 53: 152-159.

Jenssen, T. A. 1977. Evolution of anoline lizard display behavior. Amer. Zool. 17:205-215.

Manzur, I. \& E. Fuentes. 1979. Polygyny and agonistic behavior in the tree-dwelling lizard Liolaemus tenuis (Iguanidae). Behav. Ecol. Sociobiol. 6:2328.

Müller, L. \& W. Hellmich. 1933. Beiträge zur Kenntnis der Herpetofauna Chiles. VIII. Bermerkungen über Liolaemus tenuis (Duméril et Bibron). Zool. Anz. 104:305-310.

NorRIs, K. S. 1967. Colour adaptation in desert reptiles and its thermal relationships. In W. W. Milstead. (ed.), Lizard ecology: a symposium, pp. 162-229. University of Missouri Press, Columbia.

Ortiz, J. C. 1981. Révision taxonomique et biologie des Liolaemus du groupe nigromaculatus (Squamata, Iguanidae). Ph.D. Thesis. Université Paris VII, Paris, France.

Pearson, O. 1977. The effect of substrate and of skin colour on thermoregulation of a lizard. Comp. Biochem. Physiol. 58:353-358.

Pincheira, D. \& H. Núñez. 2005. Las especies chilenas del genero Liolaemus Wiegmann, 1834 (Iguania: Tropiduridae: Liolaeminae). Taxonomía, sistemática y evolución. Mus. Nac. Hist. Nat., Chile 59:7486.

Quatrini, R., Albino, A, \& Barg, M. 2001. Variación morfológica y dieta en dos poblaciones de Liolaemus elongatus Koslowsky, 1896 (Iguania: Tropiduridae) del noroeste patagónico. Rev. Chil. Hist. Nat. 74:639-651.

Skoknic, A. 1957. Contribuciones al estudio de la pigmentación en los vertebrados. V. Mecanismos nerviosos y humorales en la regulación pigmentaria de los reptiles. Zooiatria 6:5-23.

SPSS, INC. 2000. Systat for Windows, Version 10.0. SPSS Inc., Chicago, Illinois.

Stuart-Fox, D. M.,A. M oussalli, N. J. M arshall \& I. P. Owens. 2003. Conspicuous males suffer higher predation risk: Visual modeling and experimental evidence from lizards. Anim. Behav. 66:541530.

Stuart-Fox, D. M.,A. M oussalli, G. R. Johnston, \& I. P. Owens. 2004. Evolution of color variation in dragon lizards: Quantitative tests of the role of crypsis and local adaptation. Evolution 58:15491559. 
Trigosso-Venario, R., A. Labra \& H. M. Niemeyer. 2002. Interactions between males of the lizard Liolaemus tenuis: Roles of familiarity and memory. Ethology 108:1-8.

Veloso, A. \& J. Navarro. 1988. Lista sistemática y distribución geográfica de anfibios y reptiles de Chile. Boll. Mus. Reg. Sci. Nat., Torino. 6:481-539.

VIDAL, M. A. 2002. Variación morfológica, cromosómica e isoenzimática en Liolaemus tenuis (Duméril \& Bibron, 1837) (Tropiduridae). Master thesis in Zoology. Facultad de Ciencias Naturales y Oceonográficas. Universidad de Concepción, Chile.

Vidal, M. A., J. C. Ortiz, M. Astorga, P. Victoriano \& M. LAMBOROT. 2004. Revision of the subspecies of Liolaemus tenuis (Duméril et Bibron, 1837) by analysis of population genetic structure. Amph. Rept. 25:438-445.

Vidal, M. A., J. C. Ortiz, C. C. Ramírez \& M. LамвоRот. 2005. Intraspecific variation in morphology and sexual dimorphism in Liolaemus tenuis (Tropiduridae). Amph. Rept. 26:343-351.

Walton, B. M. \& A. F. Bennett. 1993. Temperaturedependent color change in Kenyan Chameleons. Physiol. Zool. 66:270-287.

Watkins, G. G 1997. Intersexual signally and the functions of females coloration in the tropidurid lizard Microlophus accipitalis. Anim. Behav. 53:843-852.

ApPENDIx I. List of the individuals of Liolaemus tenuis with their geographic coordinates (latitude, longitude, altitude), used in this study and deposited in the herpetological collection of the Museo de Zoología of Universidad de Concepción, Chile (MZUC).

ApÉNDICE I. Listado de los individuos de Liolemus tenuis con sus coordenadas geográficas (latitud, longitud, altitud) usados en este estudio y depositados en la colección herpetológica del Museo de Zoología de la Universidad de Concepción.

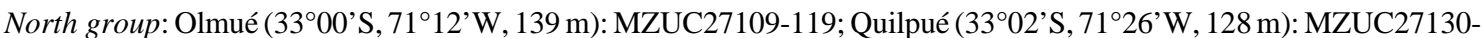

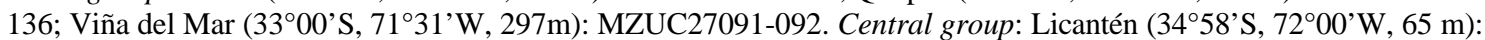

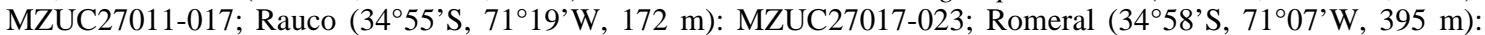

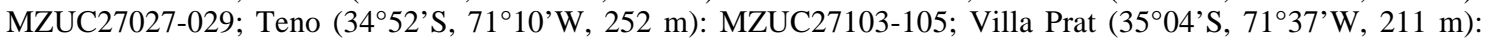

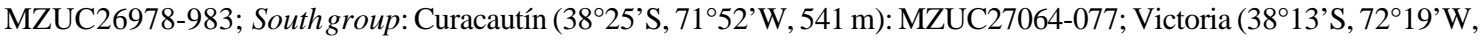
$334 \mathrm{~m})$ : MZUC27053-063. 